\title{
Enteric Coated Capsule Dosage Form
}

National Cancer Institute

\section{Source}

National Cancer Institute. Enteric Coated Capsule Dosage Form. NCI Thesaurus. Code C68945.

A capsule covered with a substance that is designed to delay the release of active and/or inert ingredient(s) until the capsule passes into the intestines. 